\title{
COMPUTER GAMES AND EDUCATION
}

\author{
Anton Sukhov \\ Assoc .Prof. Dr., Ural Federal University, Russian Federation, suhovband@mail.ru
}

\begin{abstract}
This paper devoted to the research of educational resources and possibilities of modern computer games. The "internal" educational aspects of computer games include educational mechanism (a separate or integrated "tutorial") and representation of a real or even fantastic educational process within virtual worlds. The "external" dimension represents educational opportunities of computer games for personal and professional development in different genres of computer games (various transport, social, business, medical, military simulators and economic, historical strategies).
\end{abstract}

Keywords: Computer games, virtual world, interactive study, tutorial, training, skills, education, simulator, strategy.

\section{INTRODUCTION}

Computer games are bright example of the evolution of modern audiovisual technologies. If the first computer games were, for the most part, fairly primitive arcades, many modern computer games have become full virtual worlds like "Total War: Rome II (2013), "Dragon Age 3: Inquisition" (2013) or "Fallout 4" (2015). Now computer games closely linked with education, ethics, arts, philosophy, psychology, politics, history, and even sports or gender issues. Nevertheless, despite the abundance of computer games in modern culture, the scientific exploration of this phenomenon (especially in Russian sciences) was not enough, "dotted" (Sukhov, 2015, p. 197 ) and mostly unsystematic. This applies equally to insufficiently investigate educational resources and possibilities of modern computer games.

\section{2 "INTERNAL" EDUCATIONAL ASPECTS OF COMPUTER GAMES}

Methodologically, we can identify two main educational aspects of modern computer games: "internal" and "external". The first "internal" aspect relates to education and training within virtual worlds of modern computer games.

\subsection{Internal Educational Mechanism ("Tutorial")}

The "internal" aspects of education, in its turn, include two main points. The first is that every serious computer game have internal educational mechanism (so called «tutorial»), allowing the player to understand interface and basic principles of the game mechanics. This tutorial can be: 1) a separate part of the game, where all the player's achievements vanish after finishing the tutorial ("Age of Empires II", 1999); or 2) integrated into a coherent narrative of the game, where player can use all experience from tutorial for the further game ("Dragon Age: Origins", 2009). 


\subsection{Educational Process within Virtual Worlds}

The second part of the "internal" aspects is the representation of educational process itself within virtual worlds of computer games. Firstly, it can be a detailed representation of the real learning process (e.g. "School Tycoon" or "University Tycoon"). Secondly, it can be a representation of such training (in fantasy role playing games (RPG), where player can acquires absolutely fantastic skills (levitation, telekinesis, mind reading, or ability to produce a flame from the hands (fireballs), for example, in famous RPG series "The Elder Scrolls" (1994-2014) or "Might and Magic" (1986-2014).

\section{3 "EXTERNAL" EDUCATIONAL ASPECTS OF COMPUTER GAMES}

The second "external" dimension represents educational opportunities of computer games for personal and professional development.

\subsection{Transport Simulators (driver skills)}

\subsubsection{Auto and Flight Simulators}

Primarily, from the all genres of computer games we should mention simulators and strategies. First, the genre of transport simulators that directly provide driver skills. Here we should note auto simulators that provide driver education, both city driving (study of traffic rules) and racing. For example, racing simulator game "rFactor" (2006), which was highly appreciated by Formula-1 drivers. Legendary Formula-1 seven-time champion Michael Schumacher used it as a trainer in his kart center in his hometown of Kerpen, Germany. Russian first Formula-1 driver Vitaly Petrov said: "I spent a lot of time on rFactor, studying the tracks" (Petrov, 2010, http://www.f1news.ru/interview/petrov/63108.shtml). In the genre of flight simulators, such games as famous "Microsoft Flight Simulator" ("MSFS") series (1982-2012) with their virtual three-dimensional detailed copies of the entire world with airports, airport services and airplanes make possible training pilots of civil airlines and planning their actions in emergencies.

\subsubsection{Train, Space, Navy Simulators}

The same driver skills provide different train simulators (Microsoft Train Simulator (2001), Rail Simulator (2007) or interesting "Trainz" game series (2001-2012). In the genre of space simulators we can mention "Orbiter" game (2010), which is make possible a detailed training of the real spaceship's control (Soviet "Vostok", "Soyuz" or American "Apollo" and "Space Shuttle"). In the genres of navy and submarine simulators we should mention quite simple arcade simulators "AquaNox" series (1996-2003) or detailed realistic submarine simulators "Silent Hunter" series (1996-2013). In "Silent Hunter" player not only gets submarine control skills, but also must considers the reliability of torpedoes and recharge, the time required to ascend and dive, the speed and course parameters of the submarine, the degree of damage from depth charges, the appearance of periscope and so on.

\subsection{Other Types of Simulators}

\subsubsection{Business Simulators}

Second, we should mention other types of simulators that provide interesting educational opportunities for professional development. For instance, different business simulators as a brand new way of training managers and IT professionals. In 2007, the IBM Company has introduced a three-dimensional game for business process management. Player could move freely around the building, communicated with colleagues and "received assignments from the head of the company, at first quite simple enough to understand a single business process" (Игры инноваторов, 2007, http://old.computerra.ru/2007/688/320626/). However, gradually the complexity of the game was growing and the gamer should improve his work and report on the implementation to the "authorities". At the end of the game "the trainee saw the number of points" (Ibid.). Moreover, in the online version of the game, users could not only compare the success of tasks execution, but also interact with each other to intensify the business process.

\subsubsection{Medical Simulators}

Another interesting in the educational sense types of simulators are different medical simulators, which can help to "rehearse" a surgical operation. A study published in "Archives of Surgery" suggests that enthusiasm for computer games has a positive impact on the professional skills of surgeons. Out of "33 surgeons from Beth Israel Medical Center in New York that participated in the study, the nine doctors who had at some point played video games at least three hours per week made 37 percent fewer errors, performed 27 percent faster, 
and scored 42 percent better in the test of surgical skills than the 15 surgeons who had never played video games before" (Stern, 2007, http://uk.reuters.com/article/2007/02/19/us-surgery-gamesidUKN2J30397820070219). The research supports that "there was a strong correlation between video game skills and a surgeon's capabilities performing laparoscopic surgery" (Ibid.). In fact, computer games can improve "fine motor skills, eye-hand coordination, visual attention, depth perception and computer competency"(Ibid.) and, as senior author Dr. James Rosser of Beth Israel said, "may be a practical teaching tool to help train surgeons"(Ibid.). It means that all computer games can be helpful for surgeons, but, at the same time, we can find some special surgical simulators like "Surgeon Simulator" (2013) on PC or "Surgery Simulator" on Android platform.

\subsubsection{Military Simulators}

Another interesting educational opportunity reveals in different military (soldier) simulators like "Operation Flashpoint" series (2001-2005) or "S.T.A.L.K.E.R" series (2007-2009). These games also relate to the FPS (first person shooter) genre. Gamer learns to use detailed virtual copies of real guns (rifles, pistols, revolvers, etc.) or drive military vehicles (armored troop carriers, tanks, aircrafts, etc.) and develops attention and ability to quickly make right decisions in difficult situations. It is noteworthy, that some military games like "America's Army" (2002) was specially created to attract volunteers in the U.S. Army. Remember famous "Back to the Future III" movie, when to the question "where'd you learn to shoot like that?" Marty McFly (protagonist) answered "7-Eleven". It was a store, where Marty played video game, which gave him the skill to shoot a real gun.

\subsubsection{Social, Sports, Romantic Simulators}

The same useful educational opportunities of computer games for personal and professional development present complex social simulators like "Sims" series (2000-2014), sports simulators like "FIFA" series (19932015), "NBA 2K" series (1999-2015, etc.) or even romantic rendezvous simulators like "True Love (1995-1999) or romantic simulation in modern RPG, for instance, in Dragon Age II" (2011).

\subsection{Educational Possibilities of Strategies}

\subsubsection{Economic Strategies}

In the genre of strategies, first, we should mention the genre of economic strategies that provide development of economic management skills. For example, we can see it in famous complex games "Capitalism" (1995) and "Capitalism II" (2001) which practically cover all aspects of business: marketing, production, import and export trade. The same we can find in a more simple economic strategy game "Industry Giant" (1998).

\subsubsection{Hybrid economic strategy/simulator of the city}

Another interesting economic game, that represents educational opportunities of computer games for personal and professional development is "SimCity". The famous "SimCity" series (1989-2013) also relate to the complex and multidimensional type of hybrid economic strategy/simulator of the city. "SimCity" games are especially interesting and useful for urban studies. These games not only provide a general idea about the structure of the city (city construction, city budget, taxes, power supply system, sewage system, public health, police and fire departments, urban ecology, etc.) but also help to create professional competencies and teach to accept specific decisions, regarding all residents of the city. Should the player-major of the city reduce the cost of the police to balance the budget and thereby cause the uncontrolled growth of street crime? Tear down the cemetery with monuments on a deficient ground in the historical center of the city and build a shopping mall instead? Raise taxes (and thereby cause a strikes of the taxpayers) to build a new hospital or important for the normal functioning of the city water treatment plant? Construct a factory for the recycling of toxic waste (to increase the budget's income) but get long-term environmental problems? The player-major of the "SimCity" should solve similar problems every minute of the game. In this sense, it is important that such complex games not only give player useful skills for urban management, but bring moral dimension and concept of responsibility in his decisions. Thus, educational resource of modern computer games connect with ethical issues. Veracious virtual simulation of the city (for example, in "SimCity 4", 2003) allows implementing the possible scenarios for the development of the city and safely seeing possible mistakes of the municipal government in virtual space of the computer game (in order to avoid mistakes in reality). Generally, it would be productive to test future mayors of the real cities on this simulator to identify their professional competence before they will experiment on real city residents. 


\subsection{3 "Tycoons"}

In the hybrid genre of economic simulators/strategies we cannot ignore various "tycoons". These games (there are lots of them) not only represent, perhaps, all aspects of human life, but also produce professional competences and skills to manage specific social spheres. Here we should note: "School Tycoon" (2004, school management, virtual representation of educational process itself), "Transport Tycoon" (1994, management of the transport company), "Railroad Tycoon" series (1990-2003, a detailed training of construction and management of the railways, including the historical and cultural context from the first steam locomotive to future superfast locomotives), "Hospital Tycoon" (2007, hospital management), "Roller Coaster Tycoon" series (1999-2015) and "Ultimate Skate Park Tycoon" (2001, construction and management of the entertainment park), "Zoo Tycoon" series (2001-2013, zoo construction and management), "Mail Tycoon" (2002, mail management), "Airport Tycoon" series (2003-2012, construction and management of the airport), "Luxury Liner Tycoon" (2004, design and management of luxurious passenger ocean liner), or even "Mafia Tycoon" (2005, management of the criminal sphere).

\subsubsection{Historical, Pseudo-historical and Fantastic Strategies}

In the genres of historical, pseudo-historical and fantastic strategies (real-time strategies (RTS) and turn-based strategies (TBS) we can find educational opportunities in famous "Civilization" series (1991-2014). Similar to SimCity, these games not only enable training management of cities, but a whole country, a nation. "Civilization" not only gives an idea about the main historical stages of the world culture, but also the opportunity to calculate the possible scenarios for development of humankind. The same we see in "Alpha Centauri" game (1999), but in distant future, far away on another planet. "Heroes of Might and Magic" series (1995-2011) enable training of crisis management in the conditions of limited resources. "Panzer General" series (19942013) in the game form give detailed information about the characteristics of army, weapons and military actions of the real countries, which have participated in the World War II.

Among the other historical strategies, we can see substantial innovative-educational potential in the interesting "Total War" series (2000-2015) with their "meticulous, careful attention to historical heritage" (Sukhov, 2015, p. 202). This is expressed, for example, in the creating the most accurate virtual copies of all medieval armed forces or in the "modelling historical maps with all the actually existing" (Ibid.) at specific time (for example, in the year 1181) states such as Ghaznavid Sultanate or Khorezm (in the game "Total War: Medieval II" (2006). It is interesting, that such games not only can form professional competence (in the sphere of army training management), but also provide historical education (e.g. the history of Middle Ages or Ancient history). In original "Total War: Medieval II" game and its special user versions (so-called "modes") we can see a representation of political, technical, cultural and religious backgrounds of the real medieval history (the invention of gunpowder, the elections of Pope, epidemics of plague, the announcement of Crusades, jihad, etc.). Also in the "Total War: Medieval II" modes there are many real historical characters like Byzantine Emperor Alexius Comnenus or Seljuk Sultan Kilic Arslan II. Games like "Total War: Medieval II" can be useful for history studies, because during the game "boring" history became attractive in interactive form. At the same time, after understanding the game mechanics, player can realize typical for all computer games own "alternative temporality" (Sukhov, 2014, http://media.Is.urfu.ru/221). In "Total War" game series, both in original editions and in user modes, it is possible to change or replay entire medieval history, for example, you can stop the Mongol invasion, conquer Western Europe by Novgorod principality or restore former greatness of the Eastern Roman Empire.

\subsection{MMORPG}

In the popular genre of MMORPG (massively multiplayer online role-playing game) we can see educational resource not only in historical games (like in globally popular "World of Tanks" (2010) with its detailed representation of all existing tanks of the World War II), but also in fantasy virtual worlds like "World of WarCraft" (2004) or "The Elder Scrolls Online" (2014). These fantasy games, on the one hand, represent the archetypes of fantasy literature, on the other hand, develop communication skills, professional competence of trade and management in complicated virtual social environment.

\section{INSTITUTIONAL LEVEL}

Educational possibilities of modern computer games are actual in the context of the widespread implementation of new information technologies in the educational process, both in Russia and around the world. On the institutional level in the Russia computer games are now including even in the school programs. Not very long ago, the Ministry of Education of Russia ordered the development of online-learning games to 
teach pupils and students the basics of human safety. The contest was announced in the framework of the Federal Program "Risk reduction and mitigation of consequences of emergency situations (ES) of natural and technogenic character in the Russian Federation till 2015". Ministry of Education estimated the cost of a sample in 44 million rubles. With the help of three-dimensional virtual games schoolchildren and students of higher educational institutions will practice the skills of behavior in emergencies" (Куйбида, 2011, http://izvestia.ru/news/503490). Another institutional example is the National Multimedia Centre of Ministry of Education that develops electronic educational resources, multimedia lessons, virtual labs and interactive homework in Russia. These electronic educational resources in the form of online games not only provide useful information and case studies, but also assume estimation and certification of student (even on such specific theme as "soup cooking" (Агранович, 2011, http://www.rg.ru/2011/11/01/school.html).

Eventually, modern computer games show a wide range of research opportunities that may be relevant for perspective social and educational studies.

\section{REFERENCE LIST}

Petrov V. (2010). The Chronicle of the New Year F1News.Ru chat with Vitaly Petrov. http://www.f1news.ru/interview/petrov/63108.shtml

Stern A. (2007). Surgeons who play video games more skilled: study. Reuters. http://uk.reuters.com/article/2007/02/19/us-surgery-games-idUKN2J30397820070219

Sukhov A. (2015). Computer Games and Art. Култура/Culture. No 12 (2015). http://journals.cultcenter.net/index.php/culture/article/view/196/179

Sukhov A. (2014). Immersion in Virtual Worlds: Interdisciplinary Research of Modern Computer Games. Ural Federal University. http://media.Is.urfu.ru/221

Агранович М. (2011). Приключения "стрелялок". Зачем в школах компьютерные игры? Российская газета. http://www.rg.ru/2011/11/01/school.html

Игры инноваторов. (2007). Какие компьютерные игры предпочитают бизнесмены? Компьютерра. http://old.computerra.ru/2007/688/320626

Куйбида А. (2011). Компьютерные игры включают в школьную программу. На уроках ОБЖ детям предложат трехмерные виртуальные катастрофы. Известия. http://izvestia.ru/news/503490 